\title{
General Principles of Good Governance in Execution in State Administrative Courts
}

\author{
Dezonda. R. Pattipawae * \\ Doctorate Candidate at Law Faculty, Borobudur University, Jakarta and Lecturer at Faculty of Law, Pattimura \\ University, Ambon. \\ *E-mail of the corresponding author: pattipawaeonda@gmail.com
}

\begin{abstract}
Article 52 paragraph (2) of Law Number 30 Year 2014 concerning Government Administration expressly states that the legal requirements for a Decree are based on the provisions of the legislation and the General Principles of Good Governance (hereinafter abbreviated as AUPB). That is, in addition to Law Number 9 of 2004 concerning Amendments to Law Number 5 of 1986 concerning State Administrative Courts, the Government Administration Law has also provided juridical legitimacy to judges to apply AUPB as a tool to test State Administrative Decisions. Execution can be interpreted as an action in the case of a court decision that has permanent legal force (inkracht). Execution of court decisions is the implementation of court decisions by or with the help of outside parties from the parties. Matters relating to execution are cancellation of a Decree followed by rehabilitation, administrative sanctions and execution of a decision to pay a sum of money (dwangsom). Article 116 paragraph (4) of the Administrative Court Act which states that "In the event the defendant is not willing to carry out a court decision has obtained permanent legal force, the officials concerned are subject to forced efforts in the form of payment of a number of forced money and / or administrative sanctions ". The purpose of these provisions is "officials who do not carry out court decisions that have legal force remain subject to forced money", forced money is meant to impose a form of payment of money set by the judge because of the position stated in the ruling when granting the plaintiff's claim. Forced money (dwangsom) is imposed by the judge with the intention that the decision in the principal case is carried out by the defendant (the losing party).
\end{abstract}

Key Words: AUPB, Execution, PTUN

DOI: $10.7176 / \mathrm{JLPG} / 81-16$

\section{Introduction}

The existence of a legal state is clearly stated in the constitution, one element of the rule of law is the functioning of an independent judiciary and impartial judiciary, the judiciary is a place to seek the enforcement of truth and justice (to enforce the truth and justice) in the event of a dispute or violation of law, both in framework for resolving criminal, civil and state administrative matters. The 1945 Constitution of the Republic of Indonesia (hereinafter abbreviated as 1945 Constitution of the Republic of Indonesia), Article 24 concerning judicial power. ${ }^{1}$ Indonesia as a democracy is obliged to empower its people, respect the rights of its people, and strive to realize civil society. One of the important elements of the realization of popular sovereignty and civil society is the existence of a strong State Administrative Court and can provide a sense of justice to its people. Seeing this fact, clearly the existence of the executorial institution in the State Administrative Court and its legal basis is an urgent need.

The task of the government is to realize the goals of the country as formulated in the opening of the 1945 Constitution of the Republic of Indonesia and the task is a very broad task. So wide is the scope of government administration tasks that require regulations that can direct governance to be more in line with the expectations and needs of the community (citizen friendly), in order to provide a foundation and guidelines for the Government and / or Government Officials in carrying out governmental duties.

The provision of governance is stipulated in Law Number 30 of 2014 concerning Government Administration. The Government Administration Law guarantees basic rights and provides protection to citizens and guarantees the implementation of state duties as demanded by a legal state in accordance with Article 27 paragraph (1), Article 28 D paragraph (3), Article 28 F, and Article 28 I paragraph (2) of the 1945 Constitution of the Republic of Indonesia. ${ }^{2}$ Based on these provisions, citizens do not become objects, but subjects who are actively involved in the administration of government. ${ }^{1}$

${ }^{1}$ The 1945 Constitution of the Republic of Indonesia, Article 24 concerning the judicial power of paragraph (1) states that "Judicial power is an independent power to administer the judiciary to enforce the law and justice and paragraph (2) states" Judicial power is carried out by a Supreme Court and the judiciary under him in the general court environment, religious court environment, military court environment, state administrative court environment, and by a Constitutional Court".

${ }^{2}$ The 1945 Constitution of the Republic of Indonesia, Article 27 paragraph (1) states that "All citizens are simultaneously in the law and government and must uphold the law and government with no exception. Article $28 \mathrm{D}$ paragraph (3) states that "Every citizen has the right to obtain equal opportunities in government. Article $28 \mathrm{~F}$ states that 
State of law as an opposition to government actions that tend to carry out arbitrary actions and abuse of authority which results in violations of human rights. In a rule of law, the main power lies in the law and not in the power of the government or state power. This can be seen from the restrictions on state and governmental powers based on the highest law, namely the law. Philipus M. Hadjon explained that:

"... the central idea rather than rechtsstaat is the recognition and protection of human rights which are based on the principles of freedom and equality. The existence of the constitution will provide a constitutional guarantee for the principles of freedom and equality. There is a division of power in one hand that is very inclined to power abuse, meaning rape of freedom and equality ... "2

Article 52 paragraph (2) of Law Number 30 Year 2014 concerning Government Administration (hereinafter abbreviated as Government Administration Law) expressly states that the legal requirements of a Decree are based on the provisions of the legislation and the Good Governance Principles (hereinafter abbreviated as AUPB). That is, in addition to Law Number 9 of 2004 concerning Amendments to Law Number 5 of 1986 concerning State Administrative Courts (hereinafter abbreviated as Administrative Law), the Government Administration Law has also provided juridical legitimacy to judges to implement AUPB as a test tool on the Decree of the State Administration. ${ }^{3}$

AUPB is a principle used as a reference for the use of authority for Government Officials in issuing decisions and / or actions in the administration of government. ${ }^{4}$ The AUPB was originally intended only as a means of legal protection (rechtsbescherming) and even used as an instrument to improve legal protection (verhoogde rechtsbescherming) for citizens in government actions. The AUPB is then used as a basis for judgment in the judiciary and administrative efforts, in addition to being an unwritten legal norm for acts of government (Als toetsingsgronden in the rechtspraak en het beroep. Naast toetsingsgronden en in het verlengde daarvan zijn de algemen beginselen van behaoorlijk bestuur). ${ }^{5}$ J. B. J. M. ten Berge stated that: ${ }^{6}$ "Beginselen van behoolijk bestuur komt menen in twee variant, the name of the program to be written in the right to recharge the instructor norm or the best method. Finding algemene beginselen van behaoorlijk bestuur in two variants, namely as a basis for judges and as a guiding norm for the organs of government.

To maintain the authority of the court, various administrative policies are taken in terms of administration because the characteristics of administrative actions are not only about individual interests, but also the public interest. Decision of the State Administrative Court if it has permanent legal force then the State Administration Agency or Official must carry out the obligations as stipulated in the Decision. The existence of a new State Administrative Court will be authoritative and meaningful to justice seekers, if the Decisions can be carried out by the State Administration Apparatus concerned in accordance with the contents of the Court Decision. The most basic problem of the existence of the State Administrative Court lies in adhering to or not adhering to the obligations stated in the Court Decision by the State Administration Agency or Administration. Sometimes the obligations contained in the Decision that must be carried out by the State Administration Agency or Defendant (defendant) are not implemented. Even though the State Administration Agency or Administration should have the awareness to carry out the Decision, as stipulated in the provisions of Article 116 paragraph (3) of Law Number 5 of 1986 as amended last by Law Number 51 of 2009 which states that: "In if the Defendant is determined to carry out the obligations referred to in Article 97 paragraph (9) letter b and letter c, and then after 90 (ninety) working days it turns out that the obligation is not implemented, then the Plaintiff submits an application to the Chairperson of the Court as referred to in paragraph (1), so that the Court orders the defendant to carry out the Court's Decision. ${ }^{7}$ Decisions that instruct the Defendant (Agency or State Administration Officer) to carry out the obligations that are ordered in the Decision then it becomes an obligation that must be carried out by the Defendant. Consequences for a State Administration Agency or Officer who does not carry out

"Everyone has the right to communicate and obtain information to develop their personal and social environment, as well as the right to seek, obtain, possess, store, process and convey information by using all available channels and Article 28 I paragraph ( 2) states that "Every person is free from discriminatory treatment on any basis and has the right to receive protection against such discriminatory treatment.

${ }^{1}$ General Explanation of the Law of the Republic of Indonesia Number 30 of 2014 concerning Government Administration

${ }^{2}$ Philipus M. Hadjon, 2007, Perlindungan Hukum Bagi Rakyat di Indonesia, Sebuah Studi tentang PrinsipPrinsipnya, Penanganannya oleh Pengadilan Dalam Lingkungan Peradilan Umum dan Pembentukan Peradilan Administrasi, Ed. Khusus, Cet. Ke-1, Surabaya, Peradaban, p. 71-72

${ }^{3}$ Law of the Republic of Indonesia Number 30 Year 2014 concerning Government Administration Article 52 paragraph 2 states that "The validity of the Decree as referred to in paragraph (1) is based on the provisions of laws and AUPB.

${ }^{4}$ Ibid, Article 1 number 17

${ }^{5}$ Ridwan HR, 2016, Hukum Administrasi Negara, Cet. Ke-12, Jakarta, Raja Grafindo Persada, p. 238

${ }^{6}$ J. B. J. M. ten Berge, 1995, Bescherming Tegen Overheid, Zwolle, W.E.J. Tjeenk Willink, p. 247

${ }^{7}$ J. B. J. M. ten Berge, 1995, Bescherming Tegen Overheid, Zwolle, W.E.J. Tjeenk Willink, p. 247 
a Decision that has obtained permanent legal force, the State Administration Agency or Officer is subject to payment of a number of forced money.

Arrangement of forced money in these provisions as a form of blasphemous effect to the State Administration Agency or Officer who does not respect or respect decisions issued by the State Administrative Court. Forced money is a sentence imposed by a judge on one of the parties in the form of payment of a sum of money, if the principal punishment is not carried out. ${ }^{1}$ The principle is that forced money is one of the tools for executing a Court Decision. Therefore, if the State Administration Agency or Officer does not carry out the obligations stipulated in the Decision then the forced payment is imposed as a form of redemptive effect, so that the State Administration Agency or Officer is subject to the rule of law as a form of implementation of legal supermation in the Indonesian state as state of law, so that the community (person or civil legal entity feels that there is legal protection from the state to the public).

Determination of forced money to the State Administration Agency or Officer who does not carry out its obligations stipulated in the decision in the provisions of Article 116 paragraph (4) of the Administrative Court Act, the community in this case the person or civil legal entity (plaintiff) feels this provision seems very promising to be able provide a sense of justice and legal certainty to the community. But in practice it does not or does not provide a certainty regarding the implementation of the forced money. There are various Decisions that require the State Administration Agency or Officer to carry out the Decision of the State Administrative Court but not carried out by the State Administration Agency or Officer, and to the State Administration Agency or Officer is not subject to forced money payment as stipulated in Article 116 paragraph (4) Law Number 9 of 2004. This, of course, does not provide legal protection for the interests of the community or persons or civil legal entities (plaintiffs). ${ }^{2}$

\section{Problem formulation}

Based on the background of the above problems, the problem in this paper is, How is the essence of the General Principles of Good Governance in Execution in the State Administrative Court?

\section{Research method}

The problem approach used in this writing is to use a normative juridical approach, namely library law research and because this research is carried out by having library material. In this study, the type of descriptiveanalytical research will be used for the reason that the results obtained from the literature study are then analyzed and discussed by using the systematic flow of discussion. Thus the results of the analysis and discussion are then described to facilitate the drawing of some conclusions and submission of suggestions

\section{Research Result and Discussion}

\subsection{The Nature of Good Governance General Principles}

Testing of irregularities in the use of authority (free authority) with testing parameters based on Good Governance General Principles (hereinafter abbreviated as AUPB). AUPB is an apparatus behavior norm (gedrag overheid) which is based on general norms of good behavior (algemene normen van goed overheided drag).

According to Philip M. Hadjon, it must be seen as an unwritten legal norms, which must always be obeyed by the government, even though the exact meaning of AUPB is not always a separate situation. It can also be said, that AUPB is a principle of unwritten law, from which for certain circumstances legal rules can be drawn that can be applied. ${ }^{3}$

AUPB is essentially a principle of unwritten law which was originally produced from the research of judges' decisions or jurisprudence in the Netherlands, R. Crince Le Roy on further upgrading of Constitutional Law Governance Law at the Faculty of Law of Airlangga University in 1976 suggested eleven good governance principles (principles of good administration) and those by Kuntjoro Purbopranoto in Indonesia add two principles, namely:

a. Principle of legal security;

b. Principle of proportionality;

c. Principle of equality (in decision making;

d. Principle of carefulness;

e. Motivational principle of motivation;

f. The principle of non misuse of competence;

g. The principle of fairplay;

h. Principle of a reenableness or prohibition of arbitrariness;

\footnotetext{
${ }^{1}$ Ibid.p. 17.

${ }^{2}$ Supandi, 2002, Ganti Rugi Akibat Tindakan Pejabat Pemerintah Dalam RUU Administrasi Pemerintahan Dan Prospek Peradilan Tata Usaha Negara, Medan, PT. Sofemdia, p. 1.317- 318

${ }^{3}$ Philipus M. Hadjon, 2002, Pengantar Hukum Administrasi Indonesia (Introduction to the Indonesia Adminitrative Law), Cet. Ke-8, Yogyakarta, Gajah Mada University Press, p. 270.
} 
i. Principles of meeting raised expectation;

j. The principle of undoing the consequences of an annulled decision;

$\mathrm{k}$. The principle of protecting the personal way of life;

1. Principle of wisdom (sapientia);

m. The principle of public service). ${ }^{1}$

In the AROB Jurisprudence (Administrative Court of the Netherlands) well-known principles include:

a. Principle of consideration (motiveringsbeginsel);

b. Principle of accuracy (zorgvuldgheldsbeginsel);

c. The principle of legal certainty (rechtszekerheidsbeginsel);

d. The principle of trust or principle responds to the expectations that have been generated (vertrouwensbeginsel of beginsel van opgewekte verwachtingen);

e. Principle of equality (gelijkheidsbeginsel);

f. Principle of balance (evenredigheidbeginsel);

g. The principle of authority (bevoegdheidsbeginsel);

h. Principle of fair play (beginsel van fairplay);

i. Prohibition of "detournement de power" (het verbod van detournement de pouvoir);

j. Prohibition of acting arbitrarily (het verbod van wille keur). ${ }^{2}$

AUPB as stated above, is an unwritten legal norm arising from the jurisprudence of administrative justice. As an unwritten government law norm, AUPB can always develop in accordance with the development of protection of human rights due to the actions of government based on the authority of the government. AUPB is an open concept so that the principles develop and are adapted to the time and space in which the concept is located. This brings an implication that each country has a different AUPB. Normatively, AUPB is regulated in Article 53 paragraph (2) of Law Number 9 of 2004 concerning Amendments to Law Number 5 of 1986 concerning State Administrative Courts, which states that:

"The reasons that can be used in the lawsuit as referred to in paragraph (1) are:

a. The decision of the State Administration that is sued is contrary to the laws and regulations that apply

b. The decision of the State Administration that was sued was contrary to the general principles of good governance.

In the Elucidation of Article 53 paragraph (2) letter b of Law Number 9 of 2004 states that "what is meant by the general principles of the government that is included is the principle of legal certainty; orderly state administration; openness; proportionality; professionalism; accountability; as referred to in Act Number 28 of 1999 concerning State Administrators that are Clean and free from Corruption, Collusion and Nepotism. ${ }^{3}$

The normative regulation of AUPB in the elucidation of Article 53 paragraph (2) letter b of Law Number 9 of 2004 with reference to the Principles of State Administrators as stipulated in Law Number 28 of 1999 is a mistake in the Indonesian legal system. AUPB cannot necessarily be equated with the Principles of State Administrators.

AUPB relates to administrative functions and has unwritten characteristics that are practiced in the judicial environment, while the Principles of State Administrators are related to government in general. This means that AUPB is related to the term "governance" in relation to "good governance", while the Principles of State Administrators are related to the term "government" in relation to "good governance". Between the terms "governance" with the term "government" have different substances such as the table below.

${ }^{1}$ Paulus E. Lotulung, 1994, Tata Kepemerintahan Yang Baik (Goog Governance) dalm Korelasi dengan Hukum Administrasi, dalam buku Philipus M Hadjon, Kebutuhan Akan Hukum Administrasi Umum dalam buku Philipus M. Hadjon, 2002, Pengantar Hukum Administrasi Indonesia (introduction to the Indonesia Administrative Law), Yogyakarta, Gajah Mada University Press, hal. 43, Ateng Syafrudin, Asas-Asas Pemerintahan Yang Layak Pegangan Badi Pengabdian Kepala Daerah, Pidato Pengukuhan Penerimaan Jabatan Guru Besar pada Fakultas Hukum Universitas Katolik Parayangan dalam buku Himpunan Makalah Asas-Asas Umum Pemerintahan Yang Baik, Penyusun Paulus E. Lotulung, 1994, Lembaga Penelitian dan Pengembangan Hukum Administrasi Negara, Bandung, Citra Aditya Bakti, P. 38-39.

2 Philipus M. Hadjion, 1987, Pengertian-Pengertian Dasar Tentang Tindak Pemerintahan (bestuurshandeling), Surabaya, Fakultas Hukum Universitas Airlangga, P. 9-10.

${ }^{3}$ Undang-Undang Nomor 9 Tahun 2004 tentang Perubahan atas Undang-Undang Nomor 5 Tahun 1986 tentang Peradilan Tata Usaha Negara, Pasal 53 ayat (2) berseta Penjelasannya. 
Table

\begin{tabular}{|c|c|c|c|}
\hline No. & $\begin{array}{l}\text { Comparison } \\
\text { Element }\end{array}$ & Government & Governance \\
\hline 1. & Understanding & $\begin{array}{l}\text { Can mean a body / institution } \\
\text { or function carried out by the } \\
\text { highest organ in a country }\end{array}$ & $\begin{array}{l}\text { Can mean means, use or } \\
\text { implementation }\end{array}$ \\
\hline 2. & $\begin{array}{ll}\text { Nature of } \\
\text { relationship }\end{array}$ & $\begin{array}{l}\text { Hierarchical, in the sense that } \\
\text { the ruler is above, while the } \\
\text { citizens who are governed are } \\
\text { under }\end{array}$ & $\begin{array}{l}\text { Hierakis, in the sense that there is } \\
\text { equality of position and is only } \\
\text { different in function }\end{array}$ \\
\hline 3. & $\begin{array}{l}\text { Components } \\
\text { involved }\end{array}$ & $\begin{array}{l}\text { As a subject there is only one } \\
\text { government institution }\end{array}$ & $\begin{array}{l}\text { There are three components } \\
\text { involved, namely the public } \\
\text { sector, the private sector, the } \\
\text { community }\end{array}$ \\
\hline 4. & $\begin{array}{l}\text { The dominant role } \\
\text { holder }\end{array}$ & Government sector & $\begin{array}{l}\text { All hold roles according to their } \\
\text { respective functions }\end{array}$ \\
\hline 5. & Expected effect & Citizen compliance & Citizen participation \\
\hline 6. & $\begin{array}{l}\text { Expected final } \\
\text { results }\end{array}$ & $\begin{array}{l}\text { Achieving state goals through } \\
\text { citizen compliance }\end{array}$ & $\begin{array}{l}\text { Achieving state goals and } \\
\text { community goals through } \\
\text { participation as citizens and as } \\
\text { citizens }\end{array}$ \\
\hline
\end{tabular}

Comparison of Government and Governance Ways ${ }^{1}$

In the Administrative Technical and Administrative Guidelines for State Administrative Courts, the application of AUPB with reference to the developing doctrine has been applied in the decisions of the Supreme Court (jurisprudence), namely among others:

a. Equation principle

b. Principle of trust

c. The principle of legal certainty

d. Principle of accuracy

e. The principle of giving reasons or motivation

f. Prohibition of the use of authority (detournement de pouvoir)

g. Prohibition of acting arbitrarily (willekeur)

$\mathrm{h}$. The principle that an error that an error is committed by a TUN Officer in issuing a TUN Decision which results in a loss to the justice seeker / community, may not be charged or become the risk in question

In addition to the regulation of AUPB in Law Number 9 of 2004 as mentioned above, AUPB is normatively regulated also in Law Number 30 of 2014 concerning State Administration. The types of AUPB regulated in Article 10 of Law Number 30 Year 2014 include:

a. Legal certainty;

b. Benefit;

c. Impartiality;

d. Accuracy;

e. Do not abuse authority;

f. Openness ;

g. Public interest;

h. Good service.

In the Elucidation of Article 10 of Law Number 30 Year 2014, the meaning of each principle is explained, among others: What is meant by "the principle of legal certainty" is the principle in a state of law that prioritizes the basis of the provisions of the legislation, propriety, constancy, and justice in every policy of government administration. ${ }^{2}$

What is meant by "principle of benefit" is the benefit that must be considered in a balanced manner between:

${ }^{1}$ Sadu Wasistiono, 2003, Kapita Selekta Penyelenggaraan Pemerintahan Daerah, Ed. Ke-2, Bandung, Fokus Media, p. 32.

${ }^{2}$ Mahkamah Agung Republik Indonesia, 2008, Pedoman Teknis Administrasi dan Teknis Peradilan Tata Usaha Negara, Buku II, Edisi 2007, Jakarta, Makhamah Agung Republik Indonesia, p. 63 
a. the interests of one individual with the interests of another;

b. individual interests with society;

c. the interests of Community Citizens and foreign communities;

d. the interests of one community group and the interests of other community groups;

e. government interests with Community Citizens;

f. the interests of the current generation and the interests of future generations;

g. human interest and ecosystem;

$\mathrm{h}$. the interests of men and women.

What is meant by "impartiality principle" is a principle that requires Government Agencies and / or Officials to determine and / or carry out Decisions and / or Actions by considering the interests of the parties as a whole and not discriminatory.

What is meant by "principle of accuracy" is a principle that means that a Decree and / or Action must be based on complete information and documents to support the legality of the determination and / or implementation of Decisions and / or Actions so that the Decision and / or Action concerned is prepared by be careful before the Decision and / or Action is determined and / or carried out.

What is meant by "principle of not abusing authority" is a principle that requires every Agency and / or Government Official not to use its authority for personal or other interests and not in accordance with the purpose of granting such authority, not exceeding, not misusing, and / or not confusing authority.

What is meant by "principle of openness" is the principle that serves the community to gain access and obtain information that is true, honest, and non-discriminatory in the administration of government while still paying attention to the protection of human rights, class, and state secrets.

What is meant by "principle of public interest" is the principle that prioritizes welfare and public benefit in an aspirational, accommodating, selective and non-discriminatory manner. What is meant by "principles of good service" are principles that provide timely services, clear procedures and costs, in accordance with service standards, and provisions of legislation.

AUPB is a translation of algemene beginselen van behoorlijk bestuur, a term in Dutch. In England, this principle is known as 'The Principal of Natural Justice' or 'The General Principles of Good Administration', while in France it is termed 'Les Principaux Generaux du Droit Coutumier Publique' and in Belgium it is referred to as 'Algemene Rechtsbeginselen', as well as in Germany is called 'Allgemeine Grundsätze der Ordnungsgmaben Verwaltung.

According to L.P. Suetens, ${ }^{1}$ algemene beginselen van behoorlijk bestuur is defined as general principles of good governance which is basically a rule of public law that must be followed by a court in applying positive law. These general principles of good governance are a special category of general law principles and are considered a formal source of law in administrative law, although they usually involve unwritten law. So, in carrying out his administration, the State Administration official (TUN) must be guided by the algemene beginselen van behoorlijk bestuur in carrying out his affairs in the field of state administration.

Since the adoption of the welfare state conception, which places the government as the party responsible for the general welfare of citizens and to realize this prosperity the government is given the authority to intervene in all fields of community life, which in this intervention are not only based on legislation, but based on its own initiative through Ermessen's freies, it turned out to cause concern among citizens. Because with Ermessen's freies, there are opportunities for conflicts of interest between the government and the people both in the form of onhealth overheidsdaad, detournement de pouvoir, and in the form of willekeur, which are forms of irregularities in government actions that result in the collapse of human rights of citizens. ${ }^{2}$

In 1946 the Dutch Government formed a commission led by de Monchy in charge of thinking and examining several alternatives about Verhoogde Rechtsbescherming or increasing legal protection for the people from deviant state administrative actions. In 1950 the commission de monchy then reported the results of his research on Verhoogde Rechtsbescherming in the form of "algemene beginselen van behoorlijk bestuur" or general principles of good governance. The results of the research of this commission were not entirely approved by the government or there were several things that caused differences of opinion between the de monchy commissions and the government, which caused this commission to be dissolved by the government. Then the van de Greenten commission emerged, which was also a form of government with the same task as de Monchy. But this second commission also suffered the same fate, namely because there were several opinions obtained from the results of his research that were not approved by the government and the commission was dissolved

${ }^{1}$ L.P. Suetens, Het Formuleert, zijn algemene beeginselen van behoorlijk berstuur in wezen bidende publiekrechtelijke rechtsregels die door de rechter uit geldende positieve rechtsorde worden afgeleid. Zij vormen een bijzondere categorie van de algemene rechtsbeginselen en worden beschouwd als een formele rechtsbron in het bestuurrecht, hoewel het meestal gaat om ongeschreven recht.

${ }^{2}$ Ridwan HR, Op Cit, p. 230-231. 
without fruit. ${ }^{1}$

The results of de Monchy's research were used in consideration of the decisions of Raad van State in administrative cases. In other words, although this AUPB does not easily enter the bureaucracy to be used as a norm for government action, it is not the case in the judicial region. Now it has been accepted and contained in various laws and regulations in the Netherlands.

In the Netherlands, algemene beginselen van behoorlijk bestuur, has two functions. First, as a tool for judges to examine or assess the validity of administrative actions when the provisions of the law, the decisions that apply are not clear enough to provide arrangements. Second, as a control tool to prevent administrative actions that can cause losses. In its development, the principle of algemene beginselen van behoorlijk bestuur, has been recognized and accepted as a legal norm that must be used as a basis by government officials in carrying out their authority and has also long been used as a basis for judges in deciding cases.

In the beginning, AUPB in Indonesia was not yet officially recognized legally, so it had no formal legal power so it did not have formal legal authority. When the RUU No. discussion 5 of 1986 in the DPR, the ABRI faction proposed that these principles be included as one of the reasons for the lawsuit against the Decree of the State Administration Agency / Official, but this proposal was not accepted by the government for the reasons stated by Ismael Sale, as the Minister of Justice at that time representing the government. Government reasons are as follows:

"In our opinion, in our constitutional practices as well as in the State Administration Laws that apply in Indonesia, we do not yet have the criteria for" algemene beginselen van behoorlijk bestuur "who are from the country of Beland. At that time we did not have a strong administrative tradition rooted in the continental countries. Such traditions can be developed through jurisprudence which will then lead to norms. In general, the principles of our State Administrative Law are always associated with a clean and authoritative government apparatus whose concretization of norms and understanding is still very broad and needs to be explained through concrete cases. ${ }^{2}$

The exclusion of AUPB in the PTUN Law does not mean that its existence is not recognized at all, because it turns out that what happened in the Netherlands AUPB is applied in judicial practice, especially in PTUN, as will be seen later in some examples of PTUN decisions. Even if AUPB is not accommodated in the Administrative Court Act, ${ }^{3}$ but in fact these principles can be used in the practice of justice in Indonesia because having the back in Article 10 paragraph (1) of Law Number 48 of 2009 concerning Judicial Power is confirmed "the court is prohibited from refusing to examine, adjudicate and decide on a case that is filed on the pretext that the law does not exist or is unclear, but is obliged to examine and try it. ${ }^{4}$

\subsection{Execution of State Administrative Courts}

Execution can be interpreted as an action in the case of a court decision that has permanent legal force (inkracht). Execution of court decisions is the implementation of court decisions by or with the help of outside parties from the parties. Matters relating to execution are cancellation of a Decree followed by rehabilitation, administrative sanctions and execution of a decision to pay a sum of money (dwangsom).

According to R. Subekti, it was said that the execution or execution of the decision meant that the defeated party did not want to obey the decision voluntarily so that the decision must be forced upon him with the help of the general power. ${ }^{5}$ Retno Wulan Sutantio and Iskandar Oeripkartawainata stated that the execution was an act of coercion by the court against the party lose and do not want to implement the decision voluntarily. ${ }^{6}$

Mochammad Djais, Execution in a broader sense is the attempt of creditors to realize their rights by force because the debtor does not want to voluntarily fulfill their obligations. Thus execution is part of the process of resolving legal disputes. ${ }^{7}$ Execution is not only defined in a narrow sense but also in a broad sense. Execution is not only the implementation of a decision that has a permanent legal force to the losing party, who does not want to carry out the contents of the decision voluntarily, but the execution can be carried out against notariiil debt securities and collateral collateral execution and execution of the agreement. Execution in a broad sense is an effort to reality the rights, not just the implementation of a court decision.

Execution in the State Administrative Court can be seen in 3 types of executions including the following:

${ }^{1}$ H. D. van Wijk/Willem Konijnenbelt, Hoofdstukken van Administatuef Recht, p. 386.

${ }^{2}$ Amrullah Salim, 1989, Asas-Asas Umum Pemerintahan Yang Baik berdasarkan Pancasila dan UUD NRI 1945, andung, Alumni, p. 172 P. 335 .

${ }^{3}$ SF. Marbun, 1997, Peradila Administrasi dan Upaya Adminitratif di Indonesia, Yogyakarta, Liberty,

${ }^{4}$ Ridwan HR, Op Cit, p. 240-241

${ }^{5}$ R. Subekti, 1995, Hukum Pembuktian, Jakarta, Pradnya Paramita, p. 12

${ }^{6}$ Retno Wulan Sutantio dan Iskandar Oeripkartawainata, 1999, Hukum acara Perdata Dalam Teori dan Praktek, Bandung, Mundur Maju, p. 130

${ }^{7}$ Mochammad Djais, 2000, Pikiran Dasar Hukum Eksekusi, Semarang, Fakultas Hukum Universitas Diponegoro, p. .12 


\section{a. Automatic execution}

Automatic execution is contained in Article 116 paragraphs (1) and (2) of Law Number 5 of 1986 and is not amended by Law Number 9 of 2004 and by Law Number 51 of 2009. Based on the order of the Chairperson of the Court who tried him in a degree first a copy of a court decision that has obtained permanent legal force, sent to the parties by a letter registered by the local court clerk no later than 14 (fourteen) days is changed to 14 (fourteen) working days. Decisions that require government officials or bodies to revoke the State Administration Decree (KTUN) basically require implementation. Article 116 paragraph (2) of Law Number 5 of 1986 and Law Number 9 of 2004 provides automatic settlement, that is, if within 4 (four) months after the decision is legally binding, the defendant does not carry out the revocation of the Decree The State Administration (KTUN) which has been declared null and void, the KTUN does not have legal force anymore. This automatic settlement is maintained by Law Number 51 of 2009, but the provisions of the 4 (four) month period after the legal decision is still sent and the defendant does not carry out the revocation of the object of the dispute, the KTUN has no legal force anymore by Law Number 51 Year 2009 was changed after 60 (sixty) working days were received, the defendant did not carry out the revocation of the KTUN concerned, then the disputed object has no legal force anymore. In the Administrative Technical and Technical Guidelines of State Administrative Courts (PERATUN), the Chairperson of the Court needs to make a letter stating that KTUN declared null or invalid by a court decision that has legal force still no longer has legal force. ${ }^{1}$ The letter was sent to the parties by the Registrar with a registered letter whose execution was carried out by the bailiff. In accordance with the nature of KTUN, it is still necessary to publish a statement so that the public knows that the relevant KTUN is legally enforceable.

\section{b. Hierarchical execution}

Hierarchical execution is regulated in Article 116 paragraph (3) - (5) of Law Number 5 of 1986 and is no longer applied after the enactment of Law Number 9 of 2004. Determined that in the event the defendant is determined to carry out its obligation to revoke KTUN and issue KTUN the new one or issue KTUN in the event that the object is a negative fictitious lawsuit and then after 3 (three) months it turns out that the obligation is not implemented, then the plaintiff submits an application to the head of the court, in order to order the defendant to implement the court decision. If the defendant does not implement it according to Article 116 paragraph (4) of Law Number 5 of 1986, the Chairperson of the Court, submits this matter to his superiors according to the level of office. The superiors within 2 (two) months after receiving notification from the Chief Justice must have ordered the defendant's officials to carry out the court's decision as stipulated in Article 116 paragraph (5). In the event that the superior agency does not heed it, the Chairperson of the Court shall submit this matter to the President as the holder of the highest government authority to order the relevant official to carry out a court decision (Article 116 paragraph (6)). The element of hierakis execution reappears in Law Number 51 of 2009, Article 116 paragraph (6) the Chairperson of the Court is required to submit a matter of disobedience of the defendant's official or the request for execution to the President as the holder of the highest government authority to order the officer to carry out the court's decision. Besides that, it also proposes to the people's representative institutions to carry out the supervisory function.

\section{c. Execution of forced efforts}

The implementation of hierarchy mechanism for the success rate of the implementation of decisions in the State Administrative Court is relatively low, ie 30 to 40 percent. With the birth of this mechanism of forced effort, many parties hope that this instrument will be able to make a significant contribution to the effectiveness of the implementation of the State Administrative Court's decisions in the future. Renewal of Article 16 of Law Number 5 of 1986 with paragraph (3) to paragraph (6) of Law Number 51 of 2009 changes the mechanism for the implementation of the State Administrative Court's Decision from hierarchical execution to forced efforts. This change is as a correction to the weak power (power) of the judiciary that provides legislation and is considered not able to put pressure on the authorities or government agencies to carry out decisions. Determined in paragraph (3) Article 116 of Law Number 9 of 2004 that in the event that the defendant is determined to carry out his obligation to revoke the State Administration Decree (KTUN) and issue a new KTUN or issue KTUN in the event that the object is a negative fictitious lawsuit and then after 3 ( three) months after the decision was delivered to the defendant, according to Law Number 51 Year 2009, the 90 (nine recovered) grace period of work since it was received and it turned out that the obligation was not implemented, the plaintiff submitted an application to the Chairperson of the Court who tried at the first level to order the defendant carry out the court's decision. The amendment to Law Number 51 of 2009 basically did

\footnotetext{
${ }^{1}$ Ibid, p. 65-68
} 
not change the method of this forced effort.

In the Administrative Administration and Technical Administration Guidelines for State Administration, mention execution:

a. A decision that can be implemented is a decision that has permanent legal force, that is, if the parties accept the contents of the decision, or if there has been no appeal for appeal or cassation. Administratively to mark that the decision has permanent legal force, the clerk makes a note on the final page of the original decision.

b. The implementation of a court decision that has legal force remains with the Defendant.

c. The implementation of decisions that have obtained the law still begins with:

1) Chairperson of the TUN Court / Chairperson of the TUN High Court as the first level court makes an appointment containing an order to the court clerk to send a copy of the decision to the parties by registered letter no later than 14 (fourteen) working days counted since the court's decision obtains permanent legal force.

2) The court clerk sends a copy of the court decision to the parties. Delivery is carried out by Sita on behalf of the Registrar.

3) Four months after a copy of the court decision is sent to the Defendant, and it turns out that the Defendant did not carry out his obligations as referred to in Article 97 paragraph (9) letter a of the Administrative Court Act which does not revoke the Decree of the State Administration concerned, then the Chairperson of the Court makes a letter stating the TUN Decree that has been canceled or declared invalid by the decision of the Court which has permanent legal force no longer has legal force. The letter was sent to the parties by the Registrar of the Court with a registered letter, the execution of which was carried out by the Court's Bailiff.

4) In the event that the Defendant is determined to carry out its obligations as referred to in Article 97 paragraph (9) of paragraph b and c, namely revocation of the relevant TUN Decree and issuing a new TUN Decree, or issuance of a TUN Decree in the case of a lawsuit based on Article 3, then after 3 (three) months it turns out that the obligation was not implemented, the Plaintiff filed an application so that the Chairperson of the TUN Court / Chairperson of the TUN High Court as the first level court ordered the Defendant to carry out a court decision.

5) In the event that the Defendant after being ordered to carry out the decision turns out to remain unwilling to implement it, then the Officer concerned shall be subjected to a forced effort in the form of payment of a number of forced money and / or administrative sanctions, as well as being announced in the local print mass media by the Court Clerk.

If the execution concerning Personnel as referred to in Article 97 paragraph (1) of the Administrative Court Act, as well as the execution other than those which are not or imperfectly carried out due to changes in circumstances after the decision is handed down, the Defendant shall notify the Chairperson of the Court and Plaintiff.

d. The Chairperson of the Court issues a determination that the execution cannot be carried out (nonexecutable), and notifies the applicant and the Respondent of the execution as referred to in Article 116 paragraph (1) of the Administrative Court Act.

e. Within 30 days after receiving the notification, the applicant for the execution can submit an application to the Chairperson of the Court so that the execution applicant is charged with the obligation to pay the amount of money or other compensation he wishes.

f. The Chairperson of the Court further orders the Registrar to summon the two defense parties to seek an agreement on the amount of money or other compensation that must be charged to the Defendant.

g. If the attempt to reach an agreement is unsuccessful, the Chairperson of the Court with the determination accompanied by sufficient consideration to determine the amount of money or other compensation in question.

h. Determination of the Chairperson of the Court regarding the amount of money or other compensation can be submitted by both the applicant for the execution and the request for execution to the Supreme Court to be re-stipulated.

i. The decision of the Supreme Court regarding the re-stipulation of the amount of money or other compensation must be obeyed by both parties. ${ }^{1}$

Whoever is because of the Plaintiff is certainly very interested in the success of his claim. Not only success on paper, but also can actually enjoy its success, including through execution. The implementation of the

\footnotetext{
${ }^{1}$ Ibid, p. 65-68
} 
decision of the State Administrative Court is regulated in Article 115 - Article 119 of the Administrative Court Act. In Article 115 of the Act, it is determined that "only the Court's ruling that has permanent legal force can be exercised".

If the decision of the TUN Court is limited, it is not possible to create a ruling other than those specified in Article 53 paragraph (1) Jo Article 97 paragraph (7) - (11) of the Administrative Court Act. Therefore the execution of the decision of the State Administrative Court that has permanent legal force is also limited. The execution procedure has been determined definitively in Article 116 paragraph (3) - (6) of the Administrative Court Act. As is known, the execution of the Decision of the State Administrative Court that has permanent power is not real execution, as is known in the execution of the decision of a civil judge who has permanent legal force. In each execution, of course there are parties who request the implementation of the decision, and there are parties who are authorized to issue a warrant to carry out the decision and there are parties who are obliged to carry out the decision. The applicant for the execution is certainly the party who wins the case, and the party authorized to issue the order is the Chairperson of the State Administrative Court / Chair of the State Administrative High Court if the High Court is the first court, while the person who is obliged to execute the decision is the Defendant as the executor.

The execution of the decision of the State Administrative Court that has permanent legal force, in addition to being limited, can also be judged as a hopeful reward, even if it is realized in the form of an order, because there is no strict administrative sanction so far from its superiors against TUN Officers who do not heed orders to carry out decision. ${ }^{1}$

\subsection{Execution of Decisions Based on the State Administrative Court Law}

\subsubsection{Execution Based on the provisions of Law Number 5 of 1986 concerning State Administrative Courts}

Provisions on the execution of the decision of the State Administrative Court in Law Number 5 of 1986 are regulated in the fifth section concerning the implementation of the Court Decision. Article 115 to Article 119. Article 115 of Law Number 5 of 1986 stipulates that only court decisions that have obtained permanent legal force can be exercised.

The mechanism for the execution of decisions of the State Administrative Court according to the provisions stipulated in Article 116 of Act Number 5 of 1986 is as follows:

a. A copy of the court decision that has obtained permanent legal force, is sent to the parties by a letter registered by the local Court Registrar on the order of the Chairperson of the Court who hears him at the first level no later than 14 (fourteen) days.

b. In the event that 4 (four) months after the Court's decision that has obtained permanent legal force as referred to in paragraph (1) is sent the defendant does not carry out its obligations as referred to in Article 97 paragraph (9) letter a, then the disputed State Administration Decree does not have legal power again.

c. In the event the defendant is determined to carry out its obligations as referred to in Article 97 paragraph (9) letters b and c, and then after 3 (three) months it turns out that the obligation has not been implemented, the plaintiff submits an application to the Chairperson of the Court as referred to in paragraph (1), so that the court orders the defendant to carry out the court's decision.

d. If the defendant still does not want to implement it, the Chief Justice of the Court submits this matter to his superior agency according to the level of office

e. The superior agency as referred to in paragraph (4), within 2 (two) months after receiving the notification from the Chairperson of the Court must have ordered the official referred to in paragraph (3) to implement the court's decision.

f. In the event that the supervisory agency referred to in paragraph (4) does not heed the provisions referred to in paragraph (5), then the Chairperson of the Court shall submit this matter to the President as the holder of the highest government authority to order the official to carry out the court's decision.

The implementation of the decision of the State Administrative Court is known as 2 (two) types of execution of decisions, namely the execution of decisions that contain obligations as referred to in Article 98 paragraph (9) Sub a, namely (a) Revocation of the relevant State Administration and execution of decisions. which contains the obligations as referred to in Article 97 paragraph (9) Sub-b and c of Law Number 5 of 1986 , namely (b) Revocation of the Decree of the State Administration concerned and issuing a new State Administration Decree, or (c) Issuance of the State Administration Decree in the case of a lawsuit based on Article 3.

Decision of the State Administrative Court which contains the obligation to revoke KTUN to the defendant,

${ }^{1}$ I Ketut Suradnya, Ketua PT. TUN Makassar, 2004, Schorsing (Penundaan) dan Pelaksanaan Putusan (Eksekusi), Makalah yang disampaikan pada Temu Ilmiah PERATUN dalam rangka memperingati Hut PERATUN XIII, Medan, Tanggal 14 Januari 2004, P. 6. 
then the execution is carried out according to the provisions of Article 116 paragraph (2) of Act Number 5 of 1986 that is four (four) months after the court decision that has obtained permanent legal force as referred to in Article 116 paragraph (1) is sent, the defendant does not carry out his obligations, then the disputed KTUN has no legal force anymore. Philipis M Hadjon mentioned this execution mechanism as an automatic execution. ${ }^{1}$ It is said automatically if it is associated with the principle of validity (rechtmatigheid) of government actions, in this case KTUN where the principle is related to the limits of compliance with the law, then legal decisions that are not valid, by themselves do not have binding power and thus there is no obligation to fulfill the decision which is not valid and thus there is no need for execution of a decision, except for those relating to certain obligations that must be carried out in connection with the declared invalid KTUN.

The mechanism for the execution of decisions of the State Administrative Court through superiors installation is applied if there is a decision containing the obligations as stipulated in Article 97 paragraph (9) sub b and c, namely (b) revocation of the State Administration Decree in the case of a claim based on Article 3, Article 97 paragraph (10), namely the obligation referred to in paragraph (9) may be accompanied by imposition of compensation, and Article 97 paragraph (11), in the case of a court decision as referred to in paragraph (8) concerning employment, then in addition to the obligations referred to in paragraph (9) and paragraph (10), can be accompanied by the provision of rehabilitation, then the provisions on the execution of decisions are applied according to the provisions of Article 116 paragraph (3) to paragraph (6) of Law Number 5 of 1986, namely in the case that the State Administration Agency or Official is stipulated carry out the obligation as stated in the ruling to issue the State Administration Decree, but it turns out after 3 (three a) the month passes, and the obligation is not fulfilled, then the plaintiff submits an application to the Chairperson of the Court who is authorized so that the court orders the defendant to carry out the court's decision. If the defendant still does not want to implement it, the Chairperson of the Court submits this matter to his superiors according to the level of office. This superiors agency within 2 (two) months after receiving a notification from the Chairperson of the Court must have ordered the Agency or State Administration Officer who is obliged to issue the KTUN to carry out the court decision. If it turns out that the superior agency does not heed its notification, then the Chairperson of the Court submits this matter to the President as the holder of the highest authority of the government to order the State Administration Agency or Administration to carry out the relevant court decision. This method of execution is a hierarchical execution mechanism.

The intervention of the President in the execution of the decisions of the State Administrative Court is necessary because the execution of the court is not as easy as the execution of the General Courts (civil or criminal). The President as the Head of Government is responsible for the development of Civil Servants or Government Apparatus, of course, is also responsible so that every government apparatus can comply with all applicable laws and regulations, including complying with court decisions in accordance with the legal principles we adhere to. ${ }^{2}$

\subsubsection{Execution Based on the provisions of Law Number 9 of 2004 concerning Amendments to Law Number 5 of 1986 concerning State Administrative Courts}

The regulation on the execution of the State Administrative Court in Law Number 9 of 2004 is regulated in Article 116, especially those relating to the decision that contains the obligation to revoke the KTUN concerned and the issuance of the new KTUN, and the decision that contains the obligation to issue KTUN in the case of a lawsuit based on Article 3, as stipulated in Article 97 paragraph (9) sub b and c of Law Number 5 Year 1986.

Article 116 of Law Number 9 of 2004 is complete:

(1) A copy of the decision of the Court that has obtained permanent legal force, sent to the parties by a letter registered by the Local Court of Justice at the behest of the Chairperson of the Court who tried him at the first level no later than 14 (fourteen) days

(2) In the event that 4 (four) months after the decision of the Court which has obtained permanent legal force as referred to in paragraph (1) is sent, the defendant does not carry out its obligations as referred to in Article 97 letter a, the disputed KTUN does not have legal force anymore

(3) In the event that the defendant is determined to carry out his obligations as referred to in Article 97 paragraph (9) letter b and letter c, and then after 3 (three) months it turns out that the obligation is not implemented, the plaintiff submits an application to the Chairperson of the Court as referred to in paragraph ( 1) so that the Court orders the defendant to carry out the court's decision

(4) In the event the defendant is unwilling to carry out a court decision that has obtained permanent legal force, the officer concerned shall be subject to forced efforts in the form of payment of a number of forced money and / or administrative funds.

${ }^{1}$ Philipus M. Hadjon dkk, 1992, Pengantar Hukum Administrasi Indonesia, Yogyakarta, Gadjah Mada University Pers, P. 25

${ }^{2}$ Suwarma Al Muchtar, 1999, Peradilan Tata Usaha Negara, Bandung, Epsilon Grup, P. 46 
(5) The official who does not implement the court decision as referred to in paragraph (4) is announced to the local print mass media by the Registrar since the provisions as referred to in paragraph (3) are not fulfilled.

The provisions of Article 116 paragraph (4) stipulate sanctions for payment of forced money and administrative sanctions related to the definition of such sanctions. P.D. Haan said sanctions were the application of the power tool (machtsmiddelen) as a reaction to violations of administrative law norms. The hallmark of law enforcement is coercion (dwang). While the application of sanctions is a refresive step to implement compliance. Administrative law enforcement is often interpreted as the application of administrative sanctions. ${ }^{1}$

Sanctions are an important deterrent in the law, also in administrative law. In general there is no point in including obligations or restrictions for citizens in the laws and regulations of the State Administration. The rules of behavior cannot be imposed by the State Administration. An important role in sanctions in administrative law fulfills criminal law. For regulators it is important not only to prohibit actions without permission, but also to actions that are contrary to the laws and regulations that can be linked to a permit, including typical administrative law sanctions, among others: ${ }^{2}$

a. Government coercion (bestuursdang)

b.Forced money (dwangsom)

c. Administrative fine

Revocation of favorable State Administration Decrees (permits, payments, subsidies).

4.3.3. Execution Based on the provisions of Law Number 51 of 2009 concerning the Second Amendment to Law Number 5 of 1986 concerning State Administrative Courts

The regulation on the execution of the decision of the State Administrative Court in Law Number 51 Year states the procedure of execution in the State Administrative Court, as follows:

a. A copy of the decision of the Court that has obtained permanent legal force, is sent to the parties by a letter registered by the local Court clerk on the order of the chief justice who tries him at the first level no later than 14 (fourteen) working days.

b.If after 60 ( sixty) working days a court decision that has obtained permanent legal force as referred to in paragraph (1) is received by the defendant not carrying out its obligations as referred to in Article 97 paragraph (9) letter a, the disputed State Administration Decree is not have more legal power.

c. In the event that the defendant is determined to carry out its obligations as referred to in Article 97 paragraph (9) letter b and letter c, then after 90 (ninety) working days it turns out that the obligation is not implemented, the plaintiff will submit an application to the head of the court as referred to in paragraph (1), so that the court orders the defendant to carry out the court's decision.

d.In the event that the defendant is not willing to carry out a court decision that has permanent legal force, to the official concerned put on forced effort in the form of payment of a number of forced money and or administrative sanctions. e. The official who does not implement the court decision as referred to in paragraph (4) is announced to the local print mass media by the clerk since the provisions as referred to in paragraph (3) are not fulfilled $\mathrm{f}$. Besides being announced to the local print media as referred to in paragraph (5), the head of the court must submit this matter to the President as the holder of the highest government authority to order the official to carry out court decisions and representatives of the people to carry out the supervisory function. Provisions concerning the amount of forced money, types of administrative sanctions, and procedures for the implementation of forced money payments and / or administrative sanctions are regulated by legislation.

\subsection{Application of Forced Money Execution}

Lawmakers provide an alternative to the body authorized to conduct bestuursdwang to impose forced money on those who are interested in replacing Bestuursdwang, the money will be lost for each time a violation is repeated or for each day (after the stipulated time) continues. Forced money, especially intended for conditions in which bestuursdwang is practically difficult to implement or will act as a sanction that is too heavy. In the future, the law in all respects will link this alternative effort to the authority of bestuursdwang.

Factors causing non-compliance with decisions of judges of State Administrative Courts in the form of forced money include: ${ }^{3}$

a. Weak / not qualified Judge Peratun's decision itself.

A qualified judge's decision, which is formulated properly, correctly and fairly is a demand. Judges'

${ }^{1}$ Indroharto, 2000, Peradilan Tata Usaha Negara (Buku II), Jakarta, Pustaka Sinar Harapan, hal. 78.

${ }^{2}$ Nurul Qamar, 2011, Karakteristik Hukum Acara Peradilan Tata Usaha Negara, Makassar, Pustaka Refleksi, p. 56

${ }^{3}$ Martiman Prodjohamidjojo, 2002, Hukum Acara Pengadilan Tata Usaha Negara, Jakarta, Ghalia Indonesia, p. 165. 
decisions that are qualified will create authority which in turn will affect the execution of decisions. There are still many decisions by Judge Peratun (including the Determination of Postponement) which are taken without sufficient consideration, or with wrong considerations, or even imposed because of certain factors. There are important factors for creating quality judges' decisions, namely the integrity of Moral (istiqomah) Knowledge and Understanding of Material and Legal Laws of Formiil. Based on good morality and equipped with sufficient material and formal legal knowledge, it is expected that quality decisions can truly be realized. Upgrading, training and other scientific meetings among judges must be further enhanced and more focused towards the creation of quality products of the Judge's decision.

b. The level of legal awareness of the Agency or TUN Officials and the interest of the Agency / Government Officials towards the product of the disputed TUN decision. The existence of personal interests / interests of officials of the existence of TUN decisions issued and weak levels of legal awareness of the Agency or TUN Officials is very large influence on whether or not Judge Peratun's decision to comply, because the normative execution of Judge Peratun's decision rests more on the willingness of the relevant official to implement it (floating execution).

c. The absence of forced institutions in Peratun's laws and regulations governing executions. The low quality of judges' decisions and the existence of personal interests of officials and the weak level of legal awareness of government agencies / officials, coupled with the execution of Peratun rulings in the legislative regulations regulated by floating norms, makes the decision of the Peratun increasingly lacks teeth. The lack of firmness of the regulation resulted in the Agency / Officials of the TUN looking down on the judge's product named the verdict. Because after all there was no sanction if the Judge Peratun's decision was not obeyed. In theory, the law is not only regulative, so it also has sanctions and the sanctions are forced. Likewise the judiciary, as a law enforcement institution, must absolutely be equipped with an instrument of forced / forced institutions. The three Courts that have existed earlier in Indonesia have indeed been equipped with the forced institutions.

Compensation and dwangsom even though both involve paying a sum of money, but are two different things. Compensation in Law Number 5 of 1986 concerning the State Administrative Court is regulated in Article 53 paragraph (1) and Article 97 paragraph (10). Meanwhile forced money (dwangsom) is not regulated in the law. Compensation is a type of principal punishment imposed on a party proven to have committed a legal act (onrechmatige) or broken a promise (default). The payment burden if it has been decided in the judge's decision, then the amount must be fulfilled by the convicted person. ${ }^{1}$

Dwangsom is a sum of money set by the judge in a decision that is charged to the defendant and enforced if the defendant does not carry out the sentence set. Dwangsom is not a basic law, because even though a certain amount of forced money has been set in a decision, the losing party does not need to pay or is forced to pay the forced payment if they have consciously or willingly obeyed the contents of the decision. The dwangsom obligation must be fulfilled or paid when the losing party does not comply with the contents of the decision (which is condemnatory). This is the main difference between compensation and dwangsom. The nature of Dwangsom is assesoir, meaning additional punishment as a guard and can be at the same time as an enforcer so that the judge's decision is obeyed or implemented. Forced money is an indirect means of execution.

The implementation of the dwangsom in the decisions of the General Courts Judges, therefore not all Judge Peratun's decisions can be applied by the dwangsom. Only decisions that contain punishment or the obligation to perform certain actions to the losing party (condemnatory decision), which can be imposed or applied by the dangsangsom. Decisions that are declaratory (constitutional) and constitutief (decisions that negate or create new legal conditions cannot be imposed or applied by the dangsangsom.

Dwangsom is only applied if the convicted officer performs a specific action based on a judge's decision, he does not comply. Dwangsom is applied (forced) to officials if he opposes the judge's decision. When a judge issues a decision, in essence it is the role of a pseudo legislator (pseudo-legislative body), therefore the product of a judge (panel of judges) is a legal product that is equivalent to legislation. Therefore, when the TUN Officer does not comply with the judge's decision, the disobedience is categorized as a violation of law or legislation. Offenses committed by officials are violations or personal mistakes, so that the consequences of liability must also be personal liability of the person who is in office and not institutional or state. This is in line with the "error" theory developed from the Conseil d'Etat Jurisprudence which essentially distinguishes between "service deviation" and "personal personnelle". Therefore, it is appropriate if an official does not comply with or implement the judge's decision peratun, then the imposition of forced money (dwangsom / astreinte) must be charged or paid from the personal money of the person in office or the official at the time. It is unfair if the person who is in office or the official at that time. It is unfair if the personal violation of the law as a result (in the form of dwangsom payments) is charged to the State. This is certainly very different from when as an official

${ }^{1}$ Soemaryo, 1999, Tuntunan Praktek Beracara Di Peradilan Tata Usaha Negara, Jakarta, Primamedia Pustaka, p. 89. 
in carrying out tasks which, despite being in accordance with the laws and regulations, can cause harm to the community. In situations like this, the losses suffered by the community must be the responsibility of the state to compensate.

The existence of a new State Administrative Court will be authoritative and meaningful to justice seekers, if the decisions can be carried out by the State Administration apparatus concerned in accordance with the contents of the dictum of the Court's Decision. In other words, the most basic problem of the existence of the State Administrative Court lies in the compliance or not the obligations included in the Court's decision by the State Administration Agency or Administration. The implementation of the State Administrative Court Decision which is based on the awareness of the State Administration / Officials with hierarchical hierarchy (floating form) as stipulated in Article 116 of Law Number 5 of 1986, is apparently not effective enough to force State Administration Officials to execute Judge Decisions State Administrative Court. Therefore, the enforcement of forced institutions in the form of forced money payments (dwangsom / astreinte) as stated in Article 116 of Law Number 9 of 2004 states that "in the event that the Defendant is not willing to carry out a Court Decision that has obtained permanent legal force, the relevant Official shall be charged Forced Efforts in the form of payment of a number of forced money "Changes to the awareness of the State Administration Agency / Official to implement the contents of the Decision of the State Administrative Court, at least can have a psychological impact to force the concerned official to have a psychological impact to force the Official concerned to respect the Court Decision in addition It is also hoped that it can increase public trust in the existence of the State Administrative Court.

\section{Closing}

\subsection{Conclusion}

AUPB is an apparatus behavior norm (gedrag overheid) based on general norms of good behavior (the management normally vansed overheid-dragged). The absence of AUPB in the PTUN Law does not mean its existence is not recognized at all, because it turns out like what happened in the Netherlands AUPB applied in judicial practice, especially in PTUN, as will be seen later in some examples of PTUN decisions. Even if AUPB is not accommodated in the Administrative Court Act, but in fact these principles can be used in the practice of justice in Indonesia because having the back in Article 10 paragraph (1) of Law Number 48 of 2009 concerning Judicial Power is confirmed "the court is prohibited from refusing to examine, adjudicate and decide on a case that is filed on the pretext that the law does not exist or is unclear, but is obliged to examine and try it.

Execution can be interpreted as an action in the case of a court decision that has permanent legal force (inkracht). Execution of court decisions is the implementation of court decisions by or with the help of outside parties from the parties. Matters relating to execution are cancellation of Decrees followed by rehabilitation, administrative sanctions and execution of decisions to pay a sum of money (dwangsom)

The implementation of Forced Efforts in the State Administrative Court has not been able to be effective because there are no implementing regulations, only Decisions which are nature which contains the burden or obligation to carry out certain actions to the Defendant which may be subject to Forced Efforts. The burden of payment of forced money should be charged to the State Administration Agency / Officer in person because the act of not wanting to carry out the decision of the Court is classified as a personal error rather than a service mistake. The effectiveness of forced money (dwangsom) as an administrative sanction has not been implemented optimally, because there are still many who violate the rules and the implementation of the sanctions is less strict by the implementing government.

\subsection{Suggestions}

May the government be able to implement and / or regulate the institution of Forced Efforts and / or special executorial institutions against the TUN Judicial decisions that have permanent legal force, so that the administrative court ruling can be implemented and the authority of the administrative court can increase public trust in the existence of the State Administrative Court

The burden of payment of forced money should be charged to the State Administration Agency / Officer in person because the act of not wanting to carry out the decision of the Court is classified as a personal error rather than a service mistake.

\section{References}

Amrullah Salim, 1989, Asas-Asas Umum Pemerintahan Yang Baik berdasarkan Pancasila dan UUD 1945, Alumni, Bandung.

Bambang Sugiono, 2004, Penerapan Upaya Paksa dalam Putusan Pengadilan Tata Usaha Negara, 28 Agustus 2004, Makalah Workshop, Jakarta.

-------, 2005, Penerapan Upaya Paksa Dalam Putusan Pengadilan Tata Usaha Negara, Ghalia Indonesia, Jakarta.

C.S.T. Kansil, 1996, Hukum Acara Peradilan Tata Usaha Negara, Pradnya Paramita, Jakarta.

H. D. van Wijk/Willem Konijnenbelt, Hoofdstukken van Administatuef Recht. 
.

I Ketut Suradnya, Ketua PT. TUN Makassar, 2004, Schorsing (Penundaan) dan Pelaksanaan Putusan (Eksekusi), Makalah yang disampaikan pada Temu Ilmiah PERATUN dalam rangka memperingati Hut PERATUN XIII, Medan, Tanggal 14 Januari 2004.

Indroharto, 2000, Peradilan Tata Usaha Negara (Buku II),Pustaka Sinar Harapan, Jakarta.

J. B. J. M. ten Berge, 1995, Bescherming Tegen Overheid, Zwolle, W.E.J. Tjeenk Willink.

L.P. Suetens, Het Formuleert, zijn algemene beeginselen van behoorlijk berstuur in wezen bidende publiekrechtelijke rechtsregels die door de rechter uit geldende positieve rechtsorde worden afgeleid. Zij vormen een bijzondere categorie van de algemene rechtsbeginselen en worden beschouwd als een formele rechtsbron in het bestuurrecht, hoewel het meestal gaat om ongeschreven recht.

Mahkamah Agung Republik Indonesia, 2008, Pedoman Teknis Administrasi dan Teknis Peradilan Tata Usaha Negara, Buku II, Edisi 2007, Makhamah Agung Republik Indonesia, Jakarta.

Martiman Prodjohamidjojo, 2002, Hukum Acara Pengadilan Tata Usaha Negara, Ghalia Indonesia, Jakarta.

Mochammad Djais, 2000, Pikiran Dasar Hukum Eksekusi, Fakultas Hukum Universitas Diponegoro, Semarang.

Nurul Qamar, 2011, Karakteristik Hukum Acara Peradilan Tata Usaha Negara, Pustaka Refleksi, Makassar.

Paulus E. Lotulung, 1994, Asas-Asas Umum Pemerintahan Yang Baik, Lembaga Penelitian dan Pengembangan Hukum Administrasi Negara, Citra Aditya Bakti, Bandung.

Paulus Effendie Lotulung, 2000, Beberapa System Tentang Control Segi Hukum Terhadap Pemerintahan, Bhuana Ilmu Populer, Jakarta.

Philipus M. Hadjion, 1987, Pengertian-Pengertian Dasar Tentang Tindak Pemerintahan (bestuurshandeling), Fakultas Hukum Universitas Airlangga, Surabaya.

--------, 2002, Pengantar Hukum Administrasi Indonesia (Introduction to the Indonesia Adminitrative Law), Cet. Ke-8, Gajah Mada University Press, Yogyakarta.

-------, 2007, Perlindungan Hukum Bagi Rakyat di Indonesia, Sebuah Studi tentang Prinsip-Prinsipnya, Penanganannya oleh Pengadilan Dalam Lingkungan Peradilan Umum dan Pembentukan Peradilan Administrasi, Ed. Khusus, Cet. Ke-1, Peradaban, Surabaya.

Philipus M. Hadjon dkk, 1992, Pengantar Hukum Administrasi Indonesia, Gadjah Mada University Pers, Yogyakarta.

R. Soegijanto Tjakranegara, 2002, Hukum Acara Peradilan Tata Usaha Negara di Indonesia, Sinar Grafika, Jakarta.

R. Subekti, 1995, Hukum Pembuktian, Pradnya Paramita, Jakarta.

Retno Wulan Sutantio dan Iskandar Oeripkartawainata, 1999, Hukum acara Perdata Dalam Teori dan Praktek, Mundur Maju, Bandung.

Ridwan HR, 2016, Hukum Administrasi Negara, Cet. Ke-12, Raja Grafindo Persada, Jakarta.

SF. Marbun, 1997, Peradila Administrasi dan Upaya Adminitratif di Indonesia, Liberty, Yogyakarta.

-------, 2001, Menggali dan Menemukan Asas-Asas Umum Pemerintahan Yang Baik di Indonesia, tulisan pada Dimensi-Dimensi Pemikiran Hukum Administrasi Negara, UII Pres, Yogyakarta.

--------, 2003, Peradilan Hukum Administrasi dan Upaya Administrasi di Indonesia, UII-Press, Yogjakarta.

Sadu Wasistiono, 2003, Kapita Selekta Penyelenggaraan Pemerintahan Daerah, Ed. Ke-2, Fokus Media, Bandung.

Soemaryo, 1999, Tuntunan Praktek Beracara Di Peradilan Tata Usaha Negara, Primamedia Pustaka, Jakarta.

Supandi, 2002, Ganti Rugi Akibat Tindakan Pejabat Pemerintah Dalam RUU Administrasi Pemerintahan Dan Prospek Peradilan Tata Usaha Negara, PT. Sofemdia, Medan.

-------, 2004, Problematika Penerapan Eksekusi Putusan Peradilan Tata Usaha Negara terhadap Pejabat Tata Usaha Negara Daerah, 28 Agustus 2004, Makalah Workshop, Jakarta.

Suparto Wijoyo, 2005, Karakteristik Hukum Acara Peradilan Tata Usaha Negara, UNAIR Press, Yogyakarta. Suwarma Al Muchtar, 1999, Peradilan Tata Usaha Negara, Epsilon Grup, Bandung.

Law

Undang-Undang Dasar Negara Keatuan Republik Indonesia Tahun 1945.

Undang-Undang Republik Indonesia Nomor 5 Tahun 1986 tentang Peradilan Tata Usaha Negara.

Undang-Undang Republik Indonesia Nomor 9 Tahun 2004 tentang Perubahan atas Undang-Undang Nomor 5 Tahun 1986 tentang Peradilan Tata Usaha Negara.

Undang-Undang Republik Indonesia Nomor 51 Tahun 2009 tentang Perubahan Kedua atas Undang-Undang Nomor 5 Tahun 1986 tentang Peradilan Tata Usaha Negara.

Undang-Undang Nomor 23 Tahun 2014 tentang Pemerintahan Daerah.

Surat Edaran Mahkamah Agung RI Nomor 2 Tahun 1964 tentang Penghapusan Sandera (Gijzeling). 